\section{Bond Stability of Universal Adhesives Applied To Dentin Using Etch- And-Rinse or Self-Etch Strategies}

\author{
Gabriela Cardoso de Cardoso $^{1}\left(\mathbb{B}\right.$, Leina Nakanishi ${ }^{1}{ }^{(1)}$, Cristina Pereira \\ Isolan ${ }^{1}$, Patrícia dos Santos Jardim ${ }^{1}$ (D), Rafael Ratto de Moraes ${ }^{1}$ (iD
}

'Graduate Program in Dentistry,

School of Dentistry, UFPEL

- Universidade Federal de

Pelotas, Pelotas, RS, Brazil

Correspondence: Prof. Rafael Moraes, Rua Gonçalves Chaves 457, 96015-560 Pelotas, RS, Brasil. Tel: +55-53-32256741. e-mail: moraesrr@gmail.com

\begin{abstract}
This study evaluated the immediate and 6-month dentin bond strength of universal adhesives used in etch-and-rinse or self-etch bonding strategies. The adhesives tested were Ambar Universal, G-Bond, Single Bond Universal, Tetric N-Bond Universal, and Ybond Universal. Gold standard adhesives (Scotchbond Multipurpose Plus and Clearfil SE Bond) were controls. Microtensile dentin bond strength ( $\mathrm{n}=5$ teeth), $\mathrm{pH}$, and $\mathrm{C}=\mathrm{C}$ conversion $(n=3)$ were evaluated. Data were analyzed at $\alpha=0.05$. All adhesives showed differences in $\mathrm{pH}$. Ybond had intermediately strong aggressiveness, whereas the others were ultra-mild. The $\mathrm{C}=\mathrm{C}$ conversion was different in most adhesives. In the etch-and-rinse strategy, all adhesives showed similar results generally except for G-Bond, which had lower bond strength than most adhesives. G-Bond and Tetric-N-Bond showed lower bond strengths after 6 months compared with $24 \mathrm{~h}$, whereas the other adhesives had stable dentin bonds. In the self-etch strategy, G-Bond had lower bond strength than most adhesives. After 6 months, Ambar was the only adhesive showing lower dentin bond strength compared with $24 \mathrm{~h}$. Most adhesives had discreet drops in bond strength during aging when used in the self-etch strategy. The failure modes were also material dependent, with a general pattern of increased adhesive and/or pre-testing failures after storage. In conclusion, the bonding performance of universal adhesives to dentin is material dependent. Most adhesives had stable dentin bonds with results comparable to the gold standard materials, particularly when applied in the self-etch mode. In general, it seems the use of universal adhesives in dentin should not be preceded by phosphoric acid etching.
\end{abstract}

Key Words: dental bonding, polymerization, spectroscopy, fourier transform infrared; microscopy, electron.

\section{Introduction}

The clinical success of resin composite restorations depends on the effectiveness and durability of the adhesive interface (1). In contrast to enamel, bonding to dentin remains challenging because of the composition of the dentin, which has lower inorganic content, higher amount of water, and presence of collagens fibrils, in addition to other histological features such as morphological differences in dentin regions (2). In addition, the permeability of dentin increases significantly with cavity depth due to differences in the shape and number of tubules between the superficial and deeper dentin areas near the pulp (3).

Current dental adhesive systems can be classified according to the strategy that they bond to dental tissues in etch-and-rinse adhesives, which require prior etching of surfaces with $37 \%$ phosphoric acid, or self-etch adhesives, which do not require prior acid etching and bond to dental tissues by means of acidic primers. When adequately performed, these two bonding strategies may demonstrate good results in long-term bonding (4). However, there is clinical evidence of a better performance of resin composite restorations bonded to dentin when two-step, self-etch adhesives with intermediately strong aggressiveness (i.e., $\mathrm{pH}>1$ and $<2$ ) are used as compared with two-step, etch-and-rinse adhesives (5). Nonetheless, etch-and-rinse adhesives are still prevalent in many international dental markets.

As a commercial strategy from dental product companies and potentially with the aim of simplifying the bonding procedures, adhesive systems denominated "universal" or "multimode" were introduced. These adhesives are supposedly designed to promote adhesion to various restorative substrates, e.g. enamel, dentin, resin composites, ceramics, and metal alloys, although indications among products vary. Most universal adhesives also can be applied to the dentin as two-step, etch-and-rinse or one-step, self-etch bonding agents $(3,6,7)$. Laboratory studies $(8,9)$ and clinical trials $(10,11)$ have shown that universal adhesives seem to have a similar performance in bonding to dentin as compared with two-step, etchand-rise systems. However, although several commercial brands are available in the market, most of the available evidence in the literature reports findings from a single universal adhesive (i.e., Single Bond Universal, 3M ESPE, St. Paul, MN, USA), which was one of the first to mention its "universal" character. There is room for evaluating other multi-mode adhesives, especially applied to the dentin using different bonding strategies. 
The aim of the present study was to evaluate the bond strength (immediate and after 6 months of aging) of universal adhesives applied to dentin using etch-and-rinse or self-etch bonding strategies. Gold standard adhesives were tested as references for each adhesion strategy. The null-hypothesis was that the universal adhesive systems would perform similarly to each other, irrespective of the bonding strategy to dentin.

\section{Material and Methods}

\section{Study Design and Tested Materials}

In this in vitro study, a $6 \times 2 \times 2$ factorial design was used to investigate the effect of the following factors on bond strength of resin composite to dentin: adhesive system (Ambar Universal, G-Bond, Single Bond Universal, Tetric N-Bond Universal, Ybond Universal, or control), bonding strategy (etch-and-rinse or self-etch modes), and aging time ( $24 \mathrm{~h}$ or 6 months of storage in water at $37^{\circ} \mathrm{C}$ ). The manufacturer of G-Bond does not use the term "universal" but indicates that the adhesive is "effective in all conditions" of dentin. A three-step, etch-and-rinse adhesive system (Scotchbond Multipurpose Plus) and a two-step, self-etch adhesive system (Clearfil SE Bond) were tested in the control groups for each bonding strategy. The compositions and manufacturer information of the adhesives tested are presented in Table 1. The primary response-variable was microtensile bond strength to dentin. In each group, an average of 35 beam-shaped (stick) composite-dentin bonded specimens originated from 5 teeth were tested (the tooth was the experimental unit). Failure modes of the specimens fractured in the bond strength test were classified under magnification. The $\mathrm{pH}$ of the adhesives $(\mathrm{n}=3)$ was measured using a digital $\mathrm{pH}$ meter (HI2221 Calibration Check/ORP Meter; Hanna instruments, Woonsocket, $\mathrm{RI}, \mathrm{USA})$. Degree of $\mathrm{C}=\mathrm{C}$ conversion $(\mathrm{DC}, \mathrm{n}=3$ ) of the adhesives was evaluated using Fourier-transform infrared spectroscopy. For Clearfil SE Bond and Scotchbond Multipurpose Plus, the $\mathrm{pH}$ of the primer was measured.

\section{Degree of $\mathrm{C}=\mathrm{C}$ Conversion}

The DC of the adhesives $(n=3)$ was evaluated using Fourier-transform infrared spectroscopy (Prestige21; Shimadzu, Tokyo, Japan) with an attenuated total reflectance device composed of a diamond crystal. A standard volume of each adhesive was placed on the diamond crystal, the adhesive was air dried for $20 \mathrm{~s}$ for solvent evaporation and covered with a Mylar strip. A preliminary reading for unpolymerized material (monomer) was taken in the absorbance mode using 24 co-added scans and $4 \mathrm{~cm}^{-1}$ resolution. The adhesive was photoactivated for $20 \mathrm{~s}$ using a LED curing unit (Radii; SDI, Bayswater, Victoria, Australia) with $1000 \mathrm{~mW} / \mathrm{cm}^{2}$ irradiance then a second reading (polymer) was obtained. The degree of $\mathrm{C}=\mathrm{C}$ conversion (\%) was calculated as previously described (12). For Clearfil SE Bond and Scotchbond Multipurpose Plus, the DC of the bond (adhesive) was evaluated.

\section{Bond Strength Testing and Failure Modes}

Dentin specimens were obtained from 120 bovine incisors, which were cleaned, disinfected in $0.5 \%$ chloramine-T solution for seven days, and cut to remove the roots. The buccal enamel was ground to expose medium

Table 1. Compositions of the adhesive systems tested

\begin{tabular}{|c|c|c|c|}
\hline Ambar Universal & $\begin{array}{l}\text { FGM, } \\
\text { Joinville, } \\
\text { SC, Brazil }\end{array}$ & 070116 & $\begin{array}{l}\text { UDMA, HEMA, methacrylate hydrophilic monomers, methacrylate acid } \\
\text { monomers, ethanol, water, silanized silicon dioxide, camphorquinone, } \\
\text { ethyl 4-dimethylamino-benzoate, surfactant, sodium fluoride }\end{array}$ \\
\hline G-Bond & $\begin{array}{l}\text { GC, Tokyo, } \\
\text { Japan }\end{array}$ & 1309181 & $\begin{array}{l}\text { Acetone, UDMA, dimethacrylate component, phosphoric } \\
\text { acid ester monomer, photoinitiator }\end{array}$ \\
\hline Single Bond Universal & $\begin{array}{l}\text { 3M ESPE, St. } \\
\text { Paul, MN, USA }\end{array}$ & 619545 & $\begin{array}{l}\text { MDP phosphate monomer, dimethacrylate resins, HEMA, polyalkenoic } \\
\text { acid copolymer, filler, ethanol, water, initiators, silane }\end{array}$ \\
\hline Tetric N-Bond Universal & $\begin{array}{l}\text { Ivoclar } \\
\text { Vivadent, } \\
\text { Schaan, } \\
\text { Liechtenstein }\end{array}$ & U42905 & $\begin{array}{l}\text { Ethanol, phosphonic acid acrylate, Bis-GMA, HEMA, UDMA, } \\
\text { diphenyl (2,4,6- trimethylbenzoyl) phosphine oxide }\end{array}$ \\
\hline Ybond Universal & $\begin{array}{l}\text { Yller, Pelotas, } \\
\text { RS, Brazil }\end{array}$ & 2045 & $\begin{array}{l}\text { Hydrophilic methacrylate monomers, hydrophobic methacrylate monomers, } \\
\text { initiators, stabilizers, silane, ethanol, water, silanized nanoparticles }\end{array}$ \\
\hline Clearfil SE Bond & $\begin{array}{l}\text { Kuraray, } \\
\text { Osaka, Japan }\end{array}$ & $\begin{array}{l}\text { 9N0168 } \\
\text { 9U0270 }\end{array}$ & $\begin{array}{l}\text { Primer: MDP, dimethacrylate monomer, HEMA, silica, N,N-diethanol- } \\
\text { p-toluidine, CQ; Bond: HEMA, dimethacrylate monomer, Bis- } \\
\text { GMA, N,N-diethanol-p-toluidine, silica, camphorquinone }\end{array}$ \\
\hline $\begin{array}{l}\text { Scotchbond Multipurpose } \\
\text { Plus }\end{array}$ & 3M ESPE & $\begin{array}{l}\text { N782259 } \\
\text { N763504 }\end{array}$ & $\begin{array}{l}\text { Primer: Polyalkenoic acid copolymer, HEMA, water, ethanol; } \\
\text { Bond: Bis-GMA, HEMA, tertiary amines, photoinitiator }\end{array}$ \\
\hline
\end{tabular}

*Data obtained from the manufacturers. 
dentin and the dentin surfaces were wet-polished using 600grit $\mathrm{SiC}$ abrasive papers. The teeth were randomly divided into 24 groups ( $n=5$ per group), according to the adhesive system, bonding technique, and storage time tested. The adhesive systems were applied at room conditions according to the manufacturers' recommendations, as detailed in Table 2. The specimens were prepared in a randomized order. Resin composite restorations were built up on the dentin surfaces using three increments of resin composite shade A3E (Filtek Z350; 3M ESPE). Each increment was light-activated for $20 \mathrm{~s}$. Preparation of the specimens was carried out randomly. After $24 \mathrm{~h}$ storage in distilled water, the dentin-resin composite restorations were cut into beam-shaped specimens with approximately $1 \mathrm{~mm}^{2}$ bonded area using a diamond saw under running water
(Isomet 1000; Lake Bluff, IL, USA). Each tooth yielded an average of 14 sticks and all specimens were tested.

From each restored tooth, half the number of beamshaped composite-dentin bonded specimens were immediately tested ( $24 \mathrm{~h}$ ) and the other half was stored in distilled water at $37^{\circ} \mathrm{C}$ for 6 months. The stick specimens were randomly assigned to the aging times and stored in Eppendorf tubes placed in an oven. The storage medium was renewed every month. The microtensile bond strength tests were carried out on a mechanical testing machine (DL500; São José dos Pinhais, PR, Brazil). The specimens were fixed to a notched active gripping device and tested under tensile stress at a crosshead speed of $1 \mathrm{~mm} / \mathrm{min}$ until failure. Bond strength values (MPa) for all beam-shaped specimens tested from a same tooth assigned to each

Table 2. Details of the application of the adhesive systems to dentin following the manufacturers' directions

\begin{tabular}{|c|c|c|}
\hline Adhesive & Bonding strategy & Application steps \\
\hline \multirow{2}{*}{$\begin{array}{l}\text { Ambar } \\
\text { Universal }\end{array}$} & Etch-and-rinse & $\begin{array}{l}\text { The dentin was acid-etched with } 37 \% \text { phosphoric acid for } 15 \mathrm{~s} \text {, washed with air/water spray } \\
\text { for } 15 \mathrm{~s} \text {, excess dentin moisture water was removed with absorbent paper, a first layer of } \\
\text { adhesive was applied and rubbed for } 10 \mathrm{~s} \text {, a second adhesive layer was applied, the solvent } \\
\text { was evaporated with air stream for } 10 \mathrm{~s} \text {, the adhesive was photoactivated for } 10 \mathrm{~s}\end{array}$ \\
\hline & Self-etch & $\begin{array}{l}\text { The surface was washed with air/water spray, excess dentin moisture water was removed with absorbent } \\
\text { paper, a first layer of adhesive was applied and rubbed for } 10 \mathrm{~s} \text {, then a second adhesive layer was } \\
\text { applied, the solvent was evaporated with air stream for } 10 \mathrm{~s} \text {, the adhesive was photoactivated for } 10 \mathrm{~s}\end{array}$ \\
\hline \multirow{2}{*}{ G-Bond } & Etch-and-rinse & $\begin{array}{l}\text { The dentin was acid-etched with } 37 \% \text { phosphoric acid for } 15 \mathrm{~s} \text {, washed with air/water spray for } 15 \mathrm{~s} \text {, } \\
\text { excess dentin moisture water was removed with absorbent paper, the adhesive was actively applied for } \\
10 \mathrm{~s} \text { followed by solvent evaporation with air stream for } 10 \mathrm{~s} \text {, the adhesive was photoactivated for } 20 \mathrm{~s}\end{array}$ \\
\hline & Self-etch & $\begin{array}{l}\text { The surface was washed with air/water spray, excess dentin moisture water was removed } \\
\text { with absorbent paper, the adhesive was applied and rubbed for } 10 \mathrm{~s} \text {, the solvent was } \\
\text { evaporated with air stream for } 5 \mathrm{~s} \text {, the adhesive was photoactivated for } 20 \mathrm{~s}\end{array}$ \\
\hline \multirow{2}{*}{$\begin{array}{l}\text { Single Bond } \\
\text { Universal }\end{array}$} & Etch-and-rinse & $\begin{array}{l}\text { The dentin was acid-etched with } 37 \% \text { phosphoric acid for } 15 \mathrm{~s} \text {, washed with air/water spray for } 15 \mathrm{~s} \text {, } \\
\text { excess dentin moisture water was removed with absorbent paper, the adhesive was actively applied } \\
\text { for } 20 \mathrm{~s} \text {, the solvent was evaporated with air stream for } 5 \mathrm{~s} \text {, the adhesive was photoactivated for } 10 \mathrm{~s}\end{array}$ \\
\hline & Self-etch & $\begin{array}{c}\text { The surface was washed with air/water spray, excess dentin moisture water was removed } \\
\text { with absorbent paper, the adhesive was applied and rubbed for } 20 \mathrm{~s} \text {, the solvent was } \\
\text { evaporated with air stream for } 5 \mathrm{~s} \text {, the adhesive was photoactivated for } 10 \mathrm{~s}\end{array}$ \\
\hline \multirow{2}{*}{$\begin{array}{l}\text { Tetric } \\
\text { N-Bond } \\
\text { Universal }\end{array}$} & Etch-and-rinse & $\begin{array}{l}\text { The dentin was acid-etched with } 37 \% \text { phosphoric acid for } 15 \mathrm{~s} \text {, washed with air/water spray for } 15 \mathrm{~s} \text {, } \\
\text { excess dentin moisture water was removed with absorbent paper, the adhesive was actively applied } \\
\text { for } 20 \mathrm{~s} \text {, the solvent was evaporated with air stream for } 5 \mathrm{~s} \text {, the adhesive was photoactivated for } 10 \mathrm{~s}\end{array}$ \\
\hline & Self-etch & $\begin{array}{c}\text { The surface was washed with air/water spray, excess dentin moisture water was removed } \\
\text { with absorbent paper, the adhesive was applied and rubbed for } 20 \mathrm{~s} \text {, the solvent was } \\
\text { evaporated with air stream for } 5 \mathrm{~s} \text {, the adhesive was photoactivated for } 10 \mathrm{~s}\end{array}$ \\
\hline \multirow{2}{*}{$\begin{array}{l}\text { Ybond } \\
\text { Universal }\end{array}$} & Etch-and-rinse & $\begin{array}{l}\text { The dentin was acid-etched with } 37 \% \text { phosphoric acid for } 15 \mathrm{~s} \text {, washed with air/water spray for } \\
15 \mathrm{~s} \text {, excess dentin moisture water was removed with absorbent paper, two layers of adhesive } \\
\text { were actively applied with rubbing action for } 10 \mathrm{~s} \text { each, the solvent was evaporated with air } \\
\text { stream for } 5 \mathrm{~s} \text { after each layer was applied, the adhesive was photoactivated for } 20 \mathrm{~s}\end{array}$ \\
\hline & Self-etch & $\begin{array}{l}\text { The surface was washed with air/water spray, excess dentin moisture water was removed } \\
\text { with absorbent paper, two layers of adhesive were applied and each rubbed for } 20 \mathrm{~s} \text {, the } \\
\text { solvent was evaporated with air stream for } 5 \mathrm{~s} \text {, the adhesive was photoactivated for } 20 \mathrm{~s}\end{array}$ \\
\hline $\begin{array}{l}\text { Scotchbond } \\
\text { Multipurpose } \\
\text { Plus }\end{array}$ & Etch-and-rinse & $\begin{array}{l}\text { The dentin was acid-etched with } 37 \% \text { phosphoric acid for } 15 \mathrm{~s} \text {, washed with air/water spray for } 15 \\
\text { s, the excess dentin moisture water was removed with absorbent paper, the primer was applied and } \\
\text { gently air-dried with air stream for } 5 \mathrm{~s} \text {, the adhesive was applied and photoactivated for } 10 \mathrm{~s}\end{array}$ \\
\hline $\begin{array}{l}\text { Clearfil } \\
\text { SE Bond }\end{array}$ & Self-etch & $\begin{array}{l}\text { The surface was washed with air/water spray, excess dentin moisture water was removed with } \\
\text { absorbent paper, the primer was applied and rubbed for } 20 \mathrm{~s} \text {, the solvent was evaporated } \\
\text { with air stream for } 5 \mathrm{~s} \text {, the adhesive was applied and photoactivated for } 20 \mathrm{~s}\end{array}$ \\
\hline
\end{tabular}


aging time were averaged, thus the tooth was considered the experimental unit ( $n=5$ per group). After the tests, all surfaces were examined using a light stereomicroscope at $40 \times$ magnification to classify the failure modes: adhesive (interfacial) failure, cohesive failure in dentin, cohesive failure in resin composite, or mixed failure (involving more than one failure mode). The predominance of each failure type at the surface was considered in the classification. Pre-testing failures (premature debondings) were also registered. Specimens with failures classified as premature or cohesive were not considered in the calculation of the microtensile bond strength values. For each group, at least five fractured specimens were coated with carbon and examined using scanning electron microscopy (JSM 6610; JEOL, Tokyo, Japan).

\section{Statistical Analysis}

Data for $\mathrm{pH}$ and $\mathrm{DC}$ were analyzed using One-Way Analysis of Variance (ANOVA). Bond strength data were submitted to a Three-Way ANOVA (adhesive system $\times$ bonding strategyxaging time). All pairwise multiple comparison procedures were carried out using the StudentNewman-Keuls' post hoc method. The statistical tests were

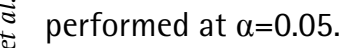

\section{Results}

\section{Ph and $\mathrm{C}=\mathrm{C}$ Conversion}

Table 3 shows the results for the $\mathrm{pH}$ and DC. All adhesives showed significant differences in $\mathrm{pH}$ when compared with each other $(p<0.001)$. The primer of Scotchbond was the least acidic material and Ybond Universal the most acidic adhesive. According to the aggressiveness of self-etch adhesives, Ybond Universal and the primer of Clearfil SE Bond can be classified as intermediately strong, whereas all the other universal adhesives tested can be classified as having ultra-mild aggressiveness $(\mathrm{pH} \geq 2.5)$. The $\mathrm{DC}$ also was significantly different among almost all adhesives tested, except between Ambar Universal and Clearfil SE Bond, and between Ybond Universal and Tetric-NBond Universal or Scotchbond. The highest DC was observed for G-Bond, while Single Bond Universal had the lowest DC.

\section{Dentin Bond Strength}

Results for the $24 \mathrm{~h}$ and 6 -month dentin bond strengths are shown in Table 4. One should note that only adhesive and mixed failures were accounted when calculating the bond strength values. The statistical analysis showed that the factors adhesive system and aging time as well as their interaction were statistically significant $(p<0.001)$. The factor bonding strategy $(p=0.758)$ and all other interactions ( $p \geq 0.207)$ were not significant. In the etch and rinse strategy at $24 \mathrm{~h}$, all adhesives showed similar results except for G-Bond, which had significantly lower bond strength than most adhesives. After 6 months, Ybond

Table 3. Means (standard deviations) for $\mathrm{pH}$ and degree of $\mathrm{C}=\mathrm{C}$ conversion (DC) of the adhesives tested, $n=3$

\begin{tabular}{lcc}
\hline Adhesive & $\mathrm{pH}$ & $\mathrm{DC}, \%$ \\
\hline Ambar Universal & $2.47(0.07) \mathrm{c}$ & $70.2(3.7) \mathrm{b}$ \\
G-Bond & $2.55(0.01) \mathrm{d}$ & $88.5(0.5) \mathrm{a}$ \\
Single Bond Universal & $2.95(0.05) \mathrm{e}$ & $33.7(2.3) \mathrm{e}$ \\
Tetric N-Bond Universal & $3.52(0.04) \mathrm{f}$ & $50.1(1.8) \mathrm{d}$ \\
Ybond Universal & $1.40(0.03) \mathrm{a}$ & $55.1(6.0) \mathrm{cd}$ \\
Scotchbond Multipurpose Plus & $3.95(0.01) \mathrm{g}$ & $61.6(0.7) \mathrm{c}$ \\
Clearfil SE Bond & $1.83(0.04) \mathrm{b}$ & $68.8(1.4) \mathrm{b}$ \\
\hline
\end{tabular}

Distinct letters in each column indicate significant differences between the adhesives $(\mathrm{p}<0.05)$.

Table 4. Means (standard deviations) for microtensile bond strength to dentin (MPa) for the adhesives applied using the etch-and-rinse of self-etch bonding strategies, $n=5$ teeth

\begin{tabular}{|c|c|c|c|c|}
\hline \multirow{2}{*}{$\begin{array}{l}\text { Bonding } \\
\text { strategy }\end{array}$} & \multirow{2}{*}{ Adhesive system } & \multicolumn{2}{|c|}{ Storage time in water at $37^{\circ} \mathrm{C}$} & \multirow{2}{*}{ Average drop } \\
\hline & & $24 \mathrm{~h}$ & 6 months & \\
\hline \multirow{5}{*}{$\begin{array}{l}\text { Etch-and- } \\
\text { rinse }\end{array}$} & Ambar Universal & $30.0(12.1)^{A, a b}$ & $28.1(8.0)^{\mathrm{A}, \mathrm{a}}$ & $6 \%$ \\
\hline & G-Bond & $25.8(5.2)^{A, b}$ & $11.8(6.2)^{\mathrm{B}, \mathrm{c}}$ & $54 \%$ \\
\hline & Single Bond Universal & $34.8(8.7)^{\mathrm{A}, \mathrm{a}}$ & $28.9(9.7)^{\mathrm{A}, \mathrm{a}}$ & $17 \%$ \\
\hline & Tetric-N-Bond Universal & $36.0(9.3)^{\mathrm{A}, \mathrm{a}}$ & $21.4(3.1)^{\mathrm{B}, \mathrm{b}}$ & $40 \%$ \\
\hline & Ybond Universal & $27.9(7.4)^{A, a b}$ & $31.6(9.3)^{A, a}$ & $-13 \%$ \\
\hline \multirow{7}{*}{ Self-etch } & Scotchbond Multipurpose Plus & $34.0(6.9)^{\mathrm{A}, \mathrm{a}}$ & $27.5(9.4)$ A,ab & $19 \%$ \\
\hline & Ambar Universal & $40.2(16.5)^{\mathrm{A}, \mathrm{a}}$ & $25.4(7.7)^{\mathrm{B}, \mathrm{ab}}$ & $37 \%$ \\
\hline & G-Bond & $21.8(3.0) \mathrm{A}, \mathrm{b}$ & $21.0(9.8)^{A, b}$ & $4 \%$ \\
\hline & Single Bond Universal & $31.9(14.5)^{\mathrm{A}, \mathrm{a}}$ & $27.5(6.2)^{\mathrm{A}, \mathrm{a}}$ & $14 \%$ \\
\hline & Tetric-N-Bond Universal & $34.4(13.0){ }^{\mathrm{A}, \mathrm{a}}$ & $32.3(5.4)^{\mathrm{A}, \mathrm{a}}$ & $6 \%$ \\
\hline & Ybond Universal & $23.8(8.1)$ A,ab & $23.1(3.7)^{\mathrm{A}, \mathrm{b}}$ & $3 \%$ \\
\hline & Clearfil SE Bond & $34.4(13.0)$ A,a & $28.1(10.6)$ A,a & $19 \%$ \\
\hline
\end{tabular}

For each bonding strategy, distinct uppercase letters in the same line and lowercase letters in the same column indicate significant differences between aging times and adhesives $(p<0.05)$. The bonding strategy was not a statistically significant factor. 
Universal, Single Bond Universal, and Ambar Universal had significantly higher bond strength than Tetric-NBond Universal, whereas G-Bond showed significantly lower bond strength than all other materials. G-Bond and Tetric-N-Bond Universal showed significantly lower bond strengths after 6 months compared with $24 \mathrm{~h}$, whereas the other adhesives had stable dentin bonding abilities in the etch-and-rinse strategy. The highest drops in bond strengths after aging were observed for G-Bond and Tetric$\mathrm{N}$-Bond Universal, whereas Ybond Universal had no bond strength drop during aging. In the self-etch strategy at 24 $h$, G-Bond had the lowest bond strength compared to all adhesives except Ybond. After 6 months, Ambar Universal was the only adhesive showing significantly lower dentin bond strength compared with $24 \mathrm{~h}$, also having the highest drop in average bond strength during aging. Most adhesives had discreet drops in dentin bond strengths during aging when used in the self-etch strategy, with results usually comparable to the control groups.

\section{Failure Modes}

Results for the failure mode analysis for all beam-shaped specimens tested in each group are shown in Figure 1. Scotchbond showed a predominance of cohesive failures in both aging times, whereas by comparison Clearfil SE Bond had more adhesive and mixed failures. These two gold standard adhesives showed increased adhesive and pre-testing failures after 6 months as compared with 24 h. Ybond Universal showed more adhesive failures in the self-etch than in the etch-and-rinse mode. After storage, adhesive failures were even more frequent in either bonding strategies. Pre-testing failures for Ybond Universal at $24 \mathrm{~h}$ were observed only for the self-etch mode, whereas after 6 months, pre-testing failures were registered for both bonding strategies.

Cohesive failures were predominant for Single Bond Universal tested in either bonding strategies. For the etch-and-rinse mode, the frequency of adhesive and premature failures increased after storage. Tetric-N-Bond Universal had pre-testing failures only when applied using the self-etch strategy. The frequency of adhesive failures increased after storage, especially in the etch-and-rinse mode. G-Bond had most failures classified as adhesive in all testing conditions except in the etch-and-rinse

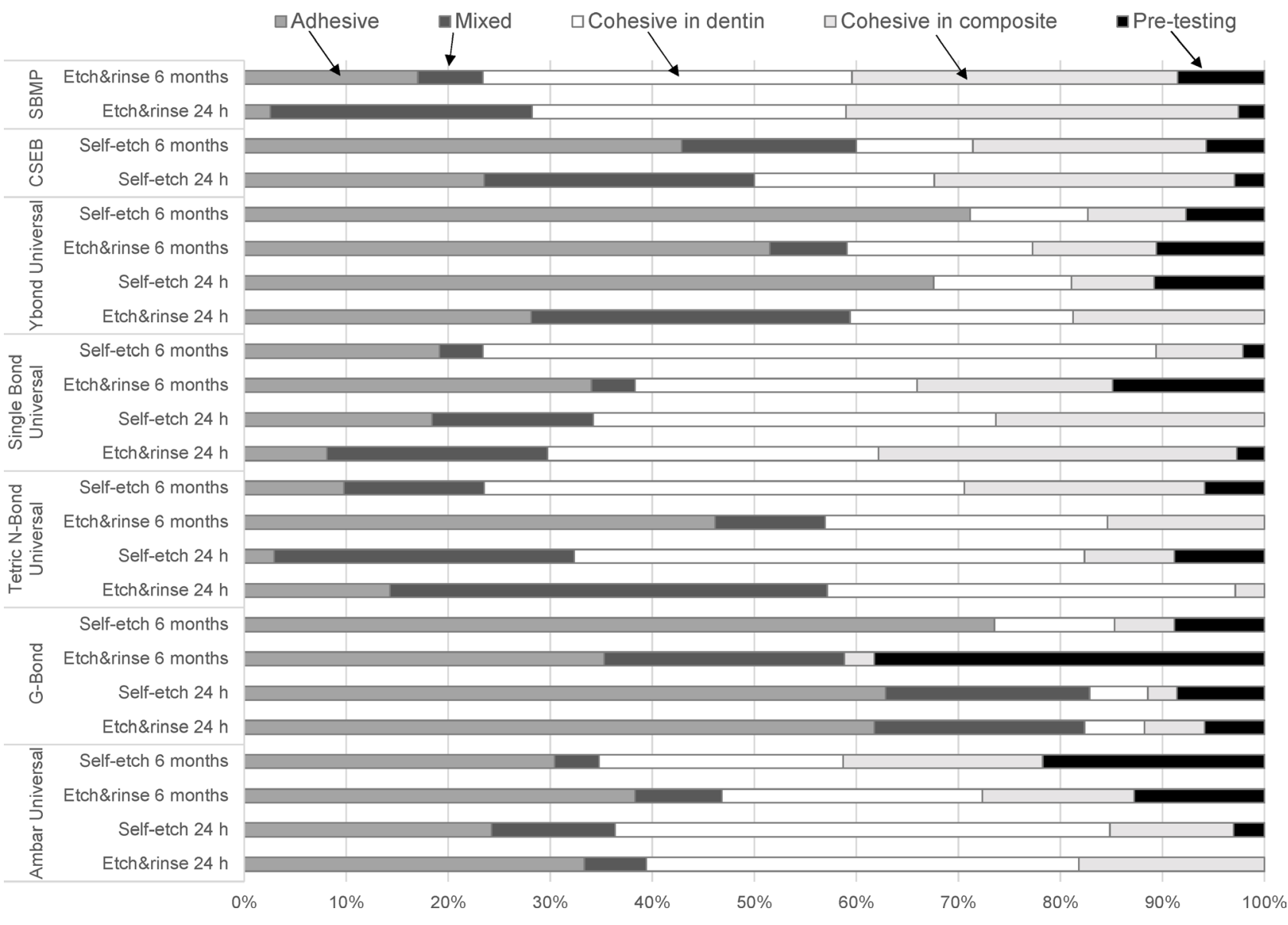

Figure 1. Distribution of failure modes across groups (SBMP: Scotchbond Multipurpose Plus; CSEB: Clearfil SE Bond). The failure modes were material dependent, with a general pattern of increased adhesive and/or pre-testing failures after storage. 
mode after 6 months, when the frequency of pre-testing failures was substantially increased. Ambar Universal also showed increased frequency of pre-testing failures after storage, particularly when used in the self-etch mode. SEM pictures of each failure mode are shown in Figure 2. The failure modes observed were very typical of dentin bond
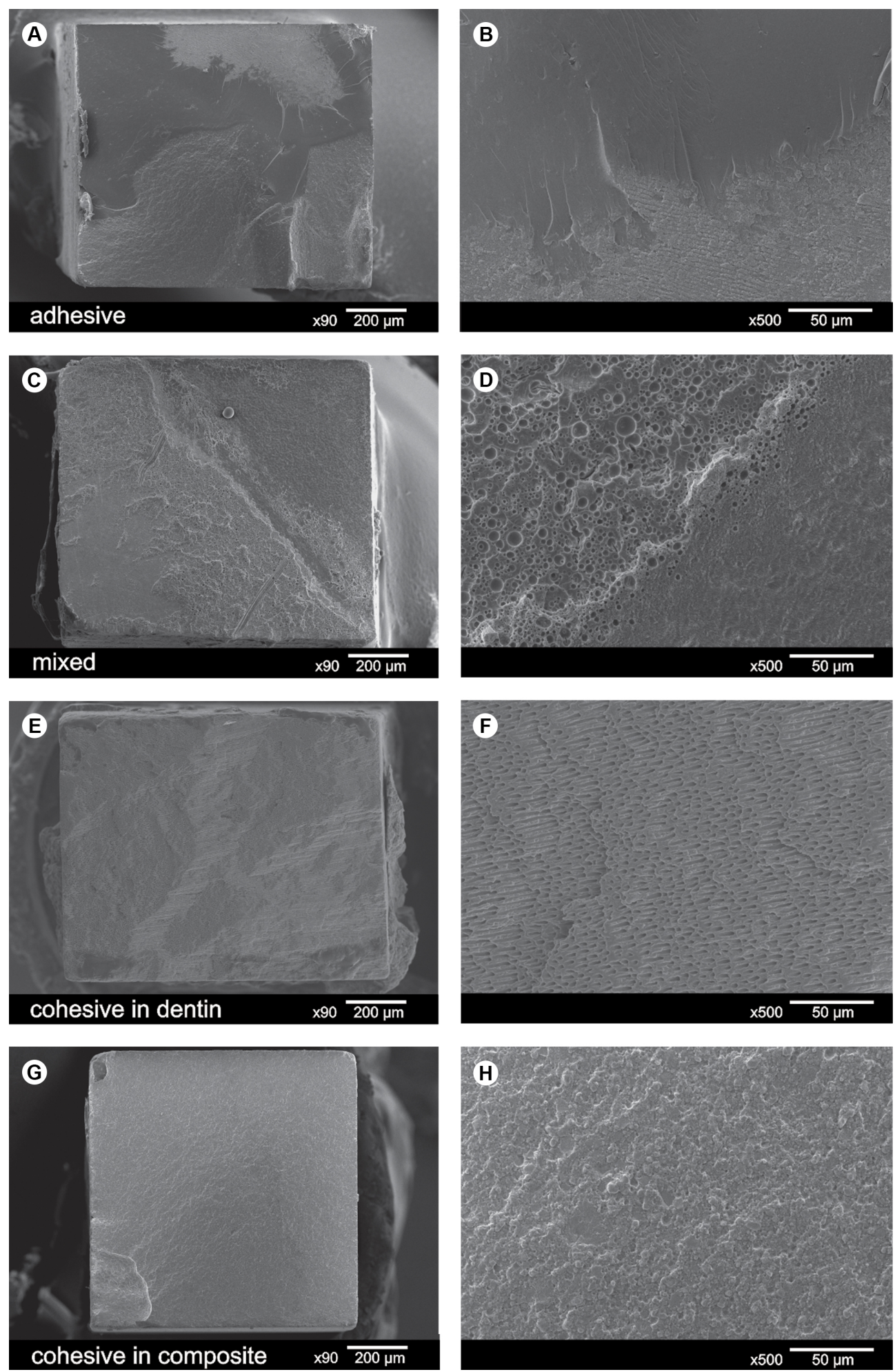

Figure 2. SEM pictures of specimens fractured in the bond strength analysis. Left hand side: $\times 90$ magnification; right hand side: $\times 500$ magnification. Adhesive failures generally involved the adhesive layer at the interface, whereas mixed failures in general involved a portion of dentin and/or composite. In the higher magnification, porosity can be seen within the resin-based materials. In cohesive failures, only dentin or resin composite can be observed at the failure sites. 
strength tests with cracks origins observed at the corners of the specimens. Adhesive failures generally involved the adhesive layer at the interface, whereas mixed failures in general involved a portion of dentin and/or composite. In the higher magnification (Fig. 2), porosity can be seen within the resin-based materials. In cohesive failures, only dentin or resin composite can be observed at the failure sites.

\section{Discussion}

The universal adhesive systems tested in this study had different performances in bonding to dentin when compared to each other. The bonding ability of the universal adhesives and failure modes were material dependent. The bonding strategy (i.e., etch-and-rinse or self-etch approach) influenced the failure modes but did not have significant effect on the bond strength of the adhesives. Finally, in some cases differences between the dentin bonding ability of the universal adhesives compared to the gold standard materials were observed. Taking all these results into account, the null-hypothesis tested could not be accepted.

The concept of having a single material able to bond adequately to the many substrates that can be found in the mouth is quite interesting. Bonding resin-based materials to different surfaces for varied applications is common in restorative dentistry. Having one specific adhesive intended for use in each bonding scenario would be not only impractical but also not cost-effective. From the standpoint of formulating multi-purpose bonding agents, it is a hard task to put many components into a single bottle (or two bottles) and expect a good bonding performance in all situations. For instance, some universal adhesives, including the Single Bond Universal tested here, have silane in their formulation, which theoretically would allow bonding to acid-sensitive ceramics without the use of a separate application of silane. However, it has been shown that the silane molecules are not stable when mixed with acidic species in universal adhesives (13) and that application of a separate silane layer to acid-etched, glass-rich ceramics should not be left out clinically $(13,14)$. Another study (15) tested the use of a universal adhesive for bonding to a zirconia ceramic and reported that a silica coating method followed by silanization promoted higher bond strength than application of the universal adhesive alone.

The present results indicate that the ability in bonding to dentin of the universal adhesives, considering both the adhesion strategy and aging times, was material dependent. The same effect was observed in the failure modes. This means that the formulation of the materials tested, including type and quantity of acidic monomers, hydrophobic and hydrophilic methacrylates, solvents, photoinitiators, and other components might affect their bonding performance. Many universal adhesives are available in the market nowadays. On one hand, this can be seen as positive fact because many companies are interested in developing new materials for clinical use. On the other hand, the negative aspect of the availability of several adhesives is that it might make the dentist to have a hard time in choosing an adhesive to purchase. In that scenario, perhaps the dentist will rely on the marketing strategies and information provided by the manufacturers in the decision process instead of appropriate evidence. This is what makes this sort of analysis reported here important in the literature. A recent study showed that there is room for improving the evidence-based practice among dentists, who often report to read articles and rely on expert's opinions for clinical decisions (16). One of the positive findings of the present study is the observation that most universal adhesives tested had bonding performances similar to the gold standard references, either before or after water storage.

A recent systematic review of in vitro studies (17) reported that the enamel bond strength of universal adhesives is improved with prior phosphoric acid etching, whereas the same effect was not evident for dentin when mild universal adhesives were used. A similar result was observed in the present study, since no overall differences in bond strength were observed between the bonding strategies. However, the occurrence of a more stable dentin bonding in the self-etch strategy is suggested by the general observation of lower average drops in bond strength after aging. The only exception was Ambar Universal, which had a more stable dentin bond when applied in the etchand-rinse mode. These findings can be contrasted with those reported in previous studies. Two studies observed that the dentin bond strength using a universal adhesive was similar in the etch-and-rinse and self-etch strategies $(6,7)$, whereas another investigation found higher bond strength in the etch-and-rinse mode (18). However, three things should be pointed out when contrasting the current findings from those of these other three studies. The first is that all three studies $(6,7,18)$ tested only one multi-mode adhesive, whereas five universal adhesives were tested herein. The second point is that, although the dentin bond strengths were similar in either bonding strategies in the study by Hanabusa et al. (6), the authors reported that the resultant adhesive interface in the etch-and-rinse approach appeared ultra-structurally more vulnerable to biodegradation compared with the self-etch approach. This finding corroborates those observed in the present investigation regarding the drop in bond strength after aging. The third point is that only immediate bond strengths were evaluated in those three studies $(6,7,18)$ and the overall results could be different if the specimens 
were submitted to any aging regimen.

In the present investigation, the specimens were stored in water at $37^{\circ} \mathrm{C}$ for six months in order to age the adhesive interfaces. According to a recent guidance paper for testing dentin bond strength using microtensile tests, a 6-month storage in water can be considered a medium to long term aging period (19). In order to accelerate the degradation process, the small beam-shaped specimens were stored, not the whole tooth-composite bonded assemblies $(20,21)$. In addition, the water in which the specimens were soaked was renewed every month to accelerate the hydrolytic process, avoiding saturation of the storage medium. Differences in bond strength between $24 \mathrm{~h}$ and 6 months were observed for some materials. In addition, all adhesives tested had increased frequency of adhesive and/or pre-testing failures after storage, indicating that it was actually able to age and challenge the bonded interfaces. The presence of aging is as important factor in the study. For instance, materials that present high immediate bond strength values but reduced bond strengths after aging may reflect adhesives that are not actually able to bond well to dentin. From the clinical standpoint, it is desirable that adhesives have stable dentin bonds during aging, even if they have yielded $\vec{\Xi}$ modest initial bond strength values.

Most adhesives had dentin bonds that can be considered stable within the storage time tested, particularly when the materials were applied as self-etch adhesives. However, it seems that G-Bond and Tetric-N-Bond Universal preferably should not be used as etch-and-rinse adhesives, since in that mode they showed $40 \%$ or more average drop in bond strength after aging. G-Bond also showed a high frequency of pre-testing failures upon storage when preceded by acid etching, reinforcing the evidence of an unstable bond. The use of Ambar Universal as selfetch adhesive warrants further investigation because an average drop of $37 \%$ in bond strength was observed after aging, whereas a more stable bonding performance was observed when the same adhesive was preceded by dentin acid etching. Interestingly, G-Bond and Ambar Universal showed the highest $\mathrm{C}=\mathrm{C}$ conversion among all adhesives tested. The monomer conversion of the adhesives as well their $\mathrm{pH}$ seemed not to be associated with their resulting dentin bonding abilities. The $\mathrm{pH}$ is mainly affect by the presence of acidic species in the formulation (22), with potential effects in the long-term mechanical properties and stability of the bonded interface if not buffered by dentin or intrinsic material components (23). In contrast, the $\mathrm{C}=\mathrm{C}$ conversion can be affected by photoactivation conditions and many formulation characteristics of dental adhesives (24), which unfortunately are not fully detailed in commercial formulations.

In conclusion, the present study indicates that the bonding performance of universal adhesives to dentin is material dependent. Most bonding agents tested had stable dentin bonds, with results comparable to the gold standard materials tested, particularly when the universal adhesives were applied in the self-etch mode. In general, it seems that the application of universal adhesives to dentin should not be preceded by phosphoric acid etching, although a case-by-case analysis is warranted.

\section{Resumo}

Este estudo avaliou a resistência de união à dentina imediata e após 6 meses de adesivos universais utilizando estratégias de união convencional ou autocondicionante. Os adesivos testados foram Ambar Universal, G-Bond, Single Bond Universal, Tetric N-Bond Universal e Ybond Universal. Adesivos padrão-ouro (Scotchbond Multipurpose Plus e Clearfil SE Bond) foram os controles. Resistência de união à microtração na dentina ( $\mathrm{n}=5$ dentes), $\mathrm{pH}$ e conversão de $\mathrm{C}=\mathrm{C}(\mathrm{n}=3)$ foram avaliados. 0 s dados foram analisados considerando $\alpha=0,05$. Todos os adesivos mostraram diferenças de $\mathrm{pH}$ comparados aos demais. Ybond Universal teve agressividade intermediária forte, enquanto os outros foram ultramoderados. A conversão de $\mathrm{C}=\mathrm{C}$ foi diferente em quase todos adesivos. No modo convencional, em geral todos os adesivos mostraram resultados similares exceto G-Bond, que teve menor resistência de união que a maioria dos adesivos. G-Bond e Tetric-N-Bond mostraram resistências de união menores após 6 meses comparados a 24 $h$, enquanto os outros adesivos apresentaram estável união à dentina. No modo autocondicionante, G-Bond teve menor resistência de união que quase todos os adesivos. Após 6 meses, Ambar foi o único adesivo mostrando menor resistência de união à dentina comparado a $24 \mathrm{~h}$. A maioria dos adesivos teve discreta queda na resistência de união durante o envelhecimento quando usados na estratégia autocondicionante. Os modos de falha também foram material dependentes, com um padrão geral de mais falhas adesivas e/ou pré-teste após o armazenamento. Em conclusão, o desempenho de união de adesivos universais à dentina é material dependente. Grande parte dos adesivos apresentou estável união à dentina com resultados comparáveis ao materiais padrão-ouro, particularmente quando aplicados no modo autocondicionante. Em geral, parece que o uso de adesivos universais em dentina não deve ser precedido por condicionamento com ácido fosfórico.

\section{Acknowledgements}

This study was financed in part by the Coordenação de Aperfeiçoamento de Pessoal de Nivel Superior (CAPES), Brazil (Finance Code 001). G.C.C. is grateful to FAPERGS (PROBIC) and UFPel (PBIP-AF) for scholarships. The authors thank $3 \mathrm{M}$ for donation of the materials tested. The authors also thank CEME-Sul (Centro de Microscopia Eletronica da Zona Sul at Federal University of Rio Grande, Brazil) for electron microscopy support.

\section{References}

1. Peumans M, De Munck J, Mine A, Van Meerbeek B. Clinical effectiveness of contemporary adhesives for the restoration of non-carious cervical lesions. A systematic review. Dent Mater 2014;30:1089-1103.

2. Spencer P, Ye Q, Park J, Misra A, Bohaty BS, Singh V, et al. Durable bonds at the adhesive/dentin interface: an impossible mission or simply a moving target? Braz Dent 2012;15:4-18.

3. Perdigão J, Sezinando A, Monteiro PC. Effect of substrate age and adhesive composition on dentin bonding. Oper Dent 2013;38:267-274.

4. Pashley DH, Tay FR, Breschi L, Tjäderhane L, Carvalho RM, Carrilho M, et al. State of the art etch-and-rinse adhesives. Dent Mater 2011;27:1-16.

5. Van Meerbeek B, Yoshihara K, Yoshida Y, Mine A, De Munck J, Van Landuyt KL. State of the art of self-etch adhesives. Dent Mater 2011;27:17-28

6. Hanabusa M, Mine A, Kuboki T, Momoi Y, Van Ende A, Van Meerbeek 
B, De Munck J. Bonding effectiveness of a new "multi-mode" adhesive to enamel and dentine. J Dent 2012;40:475-484.

7. Isolan CP, Valente LL, Munchow EA, Basso GR, Pimentel AH, Schwantz $J K_{\text {, et }}$ al. Bond strength of a universal bonding agent and other contemporary dental adhesives applied on enamel, dentin, composite, and porcelain. Appl Adhes Sci 2014;2:25.

8. Muñoz MA, Luque-Martinez I, Malaquias P, Hass V, Reis A, Campanha $\mathrm{NH}$, et al. In vitro longevity of bonding properties of universal adhesives to dentin. Oper Dent 2015;40:282-292.

9. Wagner A, Wendler M, Petschelt A, Belli R, Lohbauer U. Bonding performance of universal adhesives in different etching modes. J Dent 2014;42:800-807.

10. Loguercio AD, De Paula EA, Hass V, Luque-Martinez I, Reis A, Perdigão J. A new universal simplified adhesive: $36-$ Month randomized doubleblind clinical trial. J Dent 2015;43:1083-1092.

11. Loguercio AD, Luque-Martinez IV, Fuentes $S$, Reis A, Muñoz MA. Effect of dentin roughness on the adhesive performance in non-carious cervical lesions: A double-blind randomized clinical trial. J Dent 2018;69:60-69.

12. Moraes RR, Faria-e-Silva AL, Ogliari FA, Correr-Sobrinho L, Demarco FF, Piva E. Impact of immediate and delayed light activation on selfpolymerization of dual-cured dental resin luting agents. Acta Biomater 2009;5:2095-2100.

13. Yoshihara $K$, Nagaoka N, Sonoda A, Maruo $Y$, Makita $Y$, Okihara T, et al. Effectiveness and stability of silane coupling agent incorporated in 'universal' adhesives. Dent Mater 2016;32:1218-1225.

14. Kalavacharla VK, Lawson NC, Ramp LC, Burgess JO. Influence of etching protocol and silane treatment with a universal adhesive on lithium disilicate bond strength. Oper Dent 2015;40:372-378.

15. Araujo AM, Januario AB, Moura DM, Tribst JP, Ozcan M, Souza RO. Can the application of multi-mode adhesive be a substitute to silicatized/ silanized Y-TZP ceramics? Braz Dent J 2018;29:275-281.

16. Gonçalves AP, Correa MB, Nahsan FP, Soares CJ, Moraes RR. Use of scientific evidence by dentists in Brazil: Room for improving the evidence-based practice. PLoS One 2018;13:e0203284.

17. Rosa WL, Piva $E$, Silva AF. Bond strength of universal adhesives: $A$ systematic review and meta-analysis. J Dent 2015;43:765-776.

18. Leite ML, Costa CA, Duarte RM, Andrade AK, Soares DG. Bond strength and cytotoxicity of a universal adhesive according to the hybridization strategies to dentin. Braz Dent J 2018;29:68-75.

19. Armstrong $S$, Breschi L, Ozcan M, Pfefferkorn F, Ferrari M, Van Meerbeek B. Academy of Dental Materials guidance on in vitro testing of dental composite bonding effectiveness to dentin/enamel using micro-tensile bond strength ( $\mu$ TBS) approach. Dent Mater 2017;33:133-143.

20. Hashimoto $M, O$ hno $H$, Sano $H$, Kaga $M$, Oguchi $H$. In vitro degradation of resin-dentin bonds analyzed by microtensile bond test, scanning and transmission electron microscopy. Biomaterials 2003;24:3795-3803.

21. Toledano M, Osorio R, Osorio E, Aguilera FS, Yamauti M, Pashley DH, et al. Durability of resin-dentin bonds: Effects of direct/indirect exposure and storage media. Dent Mater 2007;23:885-892.

22. Valente LL, Munchow EA, Silva MF, Manso IS, Moraes RR. Experimental methacrylate-based primers to improve the repair bond strength of dental composites - a preliminary study. Appl Adhes Sci 2014;2:6.

23. Madruga FC, Ogliari FA, Ramos TS, Bueno M, Moraes RR. Calcium hydroxide, $\mathrm{pH}$-neutralization and formulation of model self-adhesive resin cements. Dent Mater 2013;29:413-418.

24. Faria-e-Silva AL, Lima AF, Moraes RR, Piva E, Martins LR. Degree of conversion of etch-and-rinse and self-etch adhesives light-cured using OTH or LED. Oper Dent 2010;35:649-654.

Received November 5, 2018 Accepted June 6, 2019 